joined rest. In a few days the patient went down stairs, and in about a week or ten days went to school. He was of a nervous lymphatic temperament, and complained of pain sometimes along the front of the thigh, and sometimes over the sacrum. His mother went to see him at the school, and finding the boy recovering but slowly, took him off to London, and consulted a Mr. Hutton of Gloucesterplace. This lady, in writing to a friend, states that "Mr. Hutton at once pronounced the pelvis bone to be out of place, and said that ber son must immediately undergo an operation; it was rather painful, but quite successful. Ice was ordered to the hip, and Mr. Hutton would go to Manchester in a week to see the patient. Immediately after the operation he walked briskly across the room with his usual gait." In a letter to myself this lady states that Mr. Hutton discovered "a displacement of the hip-bone, and consequent fall of the pelvis."

Not knowing who Mr. Hutton is, and being unable to find his name in the Directory, I addressed a letter to him to know what he had discovered in the case, as I know that patients often make mistakes in relating medical opinions and statements. In reply to my letter, Mr. Hutton states : " The nature of the case was detatchment of the pelvis and hip, caused by a fall or some such thing. This operation is a very peculiar one; it requires a side twist. I cannot explain, but should be delighted to show you."

I shall make no comment on the above opinion. I do not know who Mr. Hutton is, but evidently he is a surgeon of great talent in diagnosis.

I am, Sir, your obedient servant,

Broughton, Winchester, July 29, 1873.

L. Owen Fox, M.D., F.R.C.S.

\section{PROGRESS OF CHOLERA IN GERMANY.}

To the Editor of THE LANCET.

SrR,-As I receive frequent inquiries regarding the progress of cholera in the centre of Germany, I venture to give you the information contained in a letter which I had yesterday from Professor Baeumler at Erlangen. The towns hitherto visited by cholera in Bavaria are Munich, Landshut, Passau, Ingolstadt, Nürnberg, and Würzburg. The latter place seems to be as yet the most westerly point reached by the disease.

The average daily number of new cases at Würzburg does not exceed 20 in a population of rather over 40,000 , and during the last days there has been a decrease in the number as well as the severity of the cases.

At Munich the epidemic has been mild, the greatest daily access of new cases being only 38 for about 160,000 inhabitants. The mortality is up to this time about 37 per cent.

I am, Sir, your obedient servant, Grosvenor-street, August 26th, $1873 . \quad$ HermanN Weber.

\section{ARMY MEDICAL DEPARTMENT.}

To the Editor of THE LANCET.

SIR,-The one cheering occasion in this depressing country is when The LANCET arrives, and we see that we have a steady powerful friend in it to advance our just claims; but "would you be surprised to hear" that the much-talked-of and written-about Warrant of March 1st, 1873 , is still, in the middle of July, a dead letter in India? Alas! it is only too true. Here, all of us lately promoted surgeons-major (April 1st, 1873) only draw the pay and allowances of assistant-surgeons, as most of us have been doing for many years past-namely, 451 rupees per mensem. We applied for the proper pay (825 rupees a month) of our new rank, which had appeared in the General Orders, gazetted, and confirmed in this country, but have been officially refused. "Disallowed" appears across our abstracts for pay and allowances, claimed each month-"as we are supernumerary to the fixed establishment of British medical officers." Now I wish I was an Indian medico, as they are at once made supernumerary after completing twelve years' service, and get the 825 rupees.

It strikes me and others that a really very pretty job has been perpetrated (at our cost), so as to give promotion simultaneously to about eighty of us youngsters (?). The majority of the batch are in India, and lots more are coming out in the first troop-ship. "India won't pay them, England has nothing to do with them, and no expense to the public is incurred by the pacifying Gazeite of April 29th last!" Thus, no doubt, someone chuckles. I will not make a remark upon this little swindle, as it might be thought disrespectful, and nothing is further from my thoughts; but I vouch for the facts, as $m y$ empty pockets also verify, and ask you, Sir, to deal with them in your editorial columns. It may prevent some of the same batch of my brother officers being too sanguine when they get their orders for first "trooper." I can assure them that their present English pay and allowances are of much greater value than 451 rupees a month here, expenses of living having doubled in India lately.

Formerly, when we were promoted in this country, we were sent home if there were no vacancies. Now this is not to be done, but all assistant-surgeons (now called surgeons) who have been five years and upwards in India are to be sent nolens volens home, taken away from regiments and batteries, so as to create vacancies for recently promoted men, who will by this move be still nothing more than departmental subalterns.

Do expose this the latest shuffe, and help

India, July 21st, 1873.

The Victims.

\section{TUNNELING THE END OF URETHRAL INSTRUMENTS. \\ To the Editor of THe LANCET.}

SrR,-I beg leave to state that the communication to THE LANCET of July $12 \mathrm{th}, 1873$, page 63 , bearing the above title, and signed "Honour to whom honour is due," contains misstatements which I desire to correct.

1. I never was " a student of medicine in Dr. Van Buren's office."

2. Dr. Van Buren had never seen tunneled urethral instruments until I made them known to him.

3. Dr. Van Buren stated to me, early in 1870, that he had never claimed to be the inventor of the tunneled sound or of any other tunneled urethral instruments.

I have the honour to be, very respectfully,

Your obedient servant,

J. W. S. GourEY, M.D.

New York, August 9th, 1873 Surgeon to Bellevue Hospital, New York, \&e.

\section{THE "ASPIRATOR."}

To the Editor of THE LANCET.

SIR,-You did me the favour to publish in THE LANCET of June $11 \mathrm{th}, 1870$, a statement proving my right of priority to the invention of the Aspirator, or exhausting needletrocar, which had been claimed by Dr. Dieulafoy, of Paris, who had taken out a patent for the sale of the instrument in London, although I had for two or three years previously exhibited it on several occasions in Paris as well as in England. I should not have troubled you again on the subject had not Dr. Dieulafoy's claim been renewed lately on the occasion of his reading a paper at the meeting of the British Medical Association. In the cause of truth and fair play I would ask you once more to permit me to refer your numerous readers to my former letter in The LANCET, since it so clearly shows how groundless are Dr. Dieulafoy's pretensions, in the face of facts repeatedly brought before his notice and that of the profession.

I am, Sir, yours faithfully,

Park-street, W., August 15th, 1873.

$$
\text { Protheroe Smith, M.D. }
$$

\section{RAPID RECOVERY AFTER LITHOTOMY.}

\section{To the Editor of THE LANCET.}

SIR,-My experience enables me to confirm your remarks in your last issue on the comparative frequency in India of rapid recoveries after lithotomy.

In 1862, when I was civil surgeon of Mozuffurgurh, near Mooltan, I operated "upon a lad about sixteen years of 
age by the usual lateral method. The urine was passed almost from the first by the urethra, the healing process was completed without any suppuration, and the patient discharged on the eighth day.

Upon comparing notes with others wbo bad also operated extensively for stone in India, I found they had met with similar cases.-I remain, Sir, yours truly,

A. R. WAGHoRn, M.D., Surgeon-Major.

Watford, August 25th, 1873 .

\section{DIGITALIS IN DELIRIUM TREMENS.}

\section{To the Editor of THE LanceT.}

SIR,-With reference to the case of delirium tremens at Ramsgate alluded to in The Lancex of August 23rd, I may say that $I$ have seen digitalis, in four-drachm doses of the tincture, given in probably fifty cases in the practice of the late Mr. Jones, of Jersey. I have myself frequently administered the drug in the same dose in cases where opium had proved of no avail, directing that the patient should be kept in a recumbent position. I never saw any fatal case, nor indeed in my own practice any alarming symptoms that could be attributed to the drug.

I am, Sir, your obedient servant.

Ieamington, August 25th, 1873.

J. E. WOOD.

\section{THE AUTUMN MANGUVRES, CANNOCK CHASE. \\ (From our own Correspondent.)}

DurINa the past week there has been an extraordinary amount of rain even for the cloud-condensing moors of the Chase, and on Sunday night a thunderstorm of unusual violence broke over the camp; yet, from the natural drainage and porous subsoil, the ground keeps wonderfully dry. The most remarkable feature in the condition of the troops is the almost complete absence of bronchitic and other chest affections, the prevalence of which in such weather was to be anticipated. The same, however, cannot be said of the horses, as they evince the result of the expensive experi. ment of economising blankets by coughing in chorus through the night.

On the 21st inst. the infantry of the 1st division marched out a distance of about five miles, advancing over the last three as if in the presence of an enemy; camp was then pitched for three bours, and the brigades subsequently retired, covering their retreat. During this there was a good opportunity of observing the relative effects of the old knapsack and the new valise upon the various regiments respectively equipped. The men fortunate enough to possess the latter expressed themselves as much less distressed than heretofore, and well pleased with the change; while those carrying the knapsack showed the disadvantage at which they were placed. It is difficult to understand why there should be so much delay in replacing a portion of the soldiers' accoutrements which is as unsuited to the present rapid movements of war as Brown Bess would be to the rifle range.

A very simple but efficacious method of preventing men seeking to be carried in the ambulance for trivial reasons appeared in "Army Corps Orders," preceding this field day. Each company was directed to be provided with tickets as follows:- "The bearer (with the regiment, but was unable to keep with it. Signed, remmanding company." Each man falling out received one of these, and presented it to the medical officer, who, if he thought fit, countersigned it, and the man then awaited the arrival of the ambulance waggon. At the end of the day the non-commissioned officer in charge of the waggon returned these with the men to their different regiments, and thus each incapable man was again brought individually to the notice of the military and medical officers of his corps.

Owing to the absence of road marching there has been a great immunity from sore feet; and this, in some regiments, has been further secured by supplying to the canteens a small quantity of "dubbing "-a mixture of lard, resin, and bees-wax, which not only makes the boots waterproof, but renders them soft and pliable; this would form a useful addition to every soldier's kit, and would be a rational substitute for blacking on service. In consequence of a soldierlike rivalry amongst the men, there have been few applicants for carriage in the ambulances; had it been otherwise, the allowance of two horses to each would have been quite insufficient to drag such a weight over the pathless moors, knee deep in heather.

The rations have been punctually served and good, with the exception of the bread, which is often issued in a state intermediate between bread and dough.

Up to the present the Manœuvres have been a great sanitary success.

\section{PARIS.}

(From our own Correspondent.)

$A_{T}$ the last meeting of the Academy of Sciences, General Morin, Director of the Conservatoire des Arts et Métiers, read a very remarkable memoir on the ventilation of the barracks of France. The learned general, who is at the same time one of the most distinguished savants of this city, showed that the French barracks were very badly ventilated, the amount of air afforded to the soldiers being only ten to twelve cubic metres per hour; whilst in England he said it was seventeen cubic metres. This most important feature of the military hygiene in France was strenuously insisted on. The cutaneous emanations, added M. Morin, increased the danger of the presence of carbonic acid in excess in the barracks, and gravely compromised the health of the soldiers. There is no doubt that this, added to an insuffieiency of the daily rations of meat, accounts for the wan and sallow looks of French soldiers generally, however lively and vivacious they may be. The General propounded various schemes for the amendment of this state of things. They tend to ensure proper ventilation for the soldiers' chambers and to obtain a complete renewal of the premises which they now inhabit, so as to avoid the diseases peculiar to military life and brought on by aggregation, and to lessen the prevalence of typhoid fever so of ten occasioned by vitiated air. On Baron Larrey's proposal, it was unanimously decided that General Morin's memoir should be sent with urgent recommendations to the Department of War. Before quitting the Academy of Sciences, I may just add that at the same sitting Professor Chevreul made known the results of the researches which he has been conducting for some time on the composition of guano. He briefly stated that this substance, so invaluable for agriculture, was composed, according to his examination, of ceric acid, carbonate of ammonia, phosphate of lime, and cerate of ammonia.

You, doubtless, remember the sensational discussions which took place here shortly before the war, both at the Medical Societies and in the general press, touching the extraordinary mortality among new-born children. The public were literally stricken with surprise, I had almost said with remorse, when it was found that 50 per cent. of the children born in Paris and sent out to be nursed in the country never returned to their parents. It was discovered that baby-farming was one of the blots of the country, a drain on human life here, almost a system of wholesale murder. Many valuable measures of reform sprang out of the public discussion of these facts. Societies for the protection of childhood were instituted, books and pampblets were distributed, and a system of surveillance organised over the baby-farms of the land. One of the excellent results of this "movement," or agitation, was the nomination of an administrative committee, composed of members of the Municipal Council of Paris and of Government officers, and appointed to watch over the proceedings of the "bureaux," or offices of wet-nurses which exist here, and which are private establishments offering wet-nurses to those who may want them. There are two descriptions of wet-nurses to be found in these institutions; some offering to suckle the children in their parents' houses in Paris, others to take away and nurse the children in the country. The amount of infant life destroyed in this latter way, the country wet-nurses neglecting or starving the children, was something enormous. At present, an active supervision is 